\title{
Novel ultraviolet absorbers derived from cashew nut shell liquid: spectrophotometric, in silico and in vitro assays
}

\author{
Emeli Moura de Araújo*a, Luiz Antônio Soares Romeiro ${ }^{\mathrm{b}, \mathrm{c}}$, Ana Paula Rodrigues ${ }^{\mathrm{c}}$, Priscilla Souza Alves ${ }^{\mathrm{c}}$, Viviane \\ Cândida da Silva ${ }^{\mathrm{d}}$, Lúcio Paulo Lima Logrado ${ }^{\mathrm{d}}$, Maria Lucília dos Santos ${ }^{\mathrm{d}}$, Maria Márcia Murta ${ }^{\mathrm{d}}$, Álvaro Augusto da \\ Costa Leitão ${ }^{\mathrm{e}}$, Sheila Garcia ${ }^{\mathrm{f}}$, Gisela Maria Dellamora-Ortiz ${ }^{\mathrm{f}}$
}

\begin{abstract}
${ }^{a}$ Departamento de Tecnologia Farmacêutica, Faculdade de Farmácia, Universidade Federal Fluminense, Niterói, RJ, Brazil; ; ${ }^{b}$ Faculdade de Ciências da Saúde, Universidade de Brasília, Brasília, DF, Brazil; ; Laboratório de Desenvolvimento de Estratégias Terapêuticas, Universidade Católica de Brasília, Brasília, DF, Brazil; ${ }^{d}$ Laboratório de Isolamento e Transformação de Moléculas Orgânicas, Instituto de Química, Universidade de Brasília, Brasília, DF, Brazil; ${ }^{e}$ Instituto de Biofisica Carlos Chagas Filho, Universidade Federal do Rio de Janeiro, Rio de Janeiro, RJ, Brazil, ${ }^{f}$ Departamento de Fármacos e Medicamentos, Faculdade de Farmácia, Universidade Federal do Rio de Janeiro, Rio de Janeiro, RJ, Brazil
\end{abstract}

\section{*Corresponding author: emeliaraujo@id.uff.br}

The use of sunscreens prevents erythema, photodamage and skin cancer. Natural products have been studied as ultraviolet (UV) absorbers due to their structural similarity to organic UV filters and their lower cost. The cashew nut shell liquid (CNSL) constituents were isolated by our group leading to four mixtures and seventeen pure compounds, which had chromophoric groups similar to organic UV filters. In addition, C15 and C8 CNSL-derivatives molecules were rationally planned as UV absorbers. The aim of this work was to evaluate the potential of CNSL's constituents and its derivatives as new UV absorbers using spectrophotometric methods, study their physical-chemical properties and toxicity using in silico method, and perform in vitro assays. Mixtures and isolated CNSL compounds were demonstrated to be non-phototoxic when evaluated in a phototoxicity assay using the yeast Saccharomyces cerevisiae. Considering the absorption values on the UV range, 6 compounds showed appropriate SPF values regarding the spectrophotometric test. Additionally, in silico and in vitro evaluations were performed, showing non-oral bioavailability, as well as nonmutagenic, non-genotoxic and non-phototoxic properties for the tested compounds. These results contribute favorably to the aimed use of the compounds under analysis as novel organic UV absorbers that have as precursor the phenolic lipid component of CNSL, a waste product obtained as the by-product of cashew nut food processing.

Keywords: ultraviolet absorbers, cashew nut, SPF, spectrophotometry

https://doi.org/10.22456/2527-2616.108405

\section{Introduction}

The Cashew tree (Anacardium occidentale L.) is a native plant of the Brazilian Northeast [1-3], cultivated in many equatorial and sub-equatorial areas of the world [1, 4]. Only six countries (Brazil, India, Madagascar, Mozambique, Kenya and Tanzania) stand out in a significant way in the production and commercial exploration of the cashew nut [1].

Cashew nut comprises the shell and the kernel. While the kernel is nutritionally valuable, the shell has been considered as a residue of cashew nut production [4]. The byproduct of the chestnut processing, the cashew nut shell liquid (CNSL), was initially used as raw material in the production of antioxidants, thermal insulation and attrition material, plasticizers, surfactants, paints and varnishes [4-7]. Its components also have antioxidant, fungicidal, molluscicidal, anti-tumor, antimicrobial, anti-inflammatory, anti-genotoxic and cytostatic activities [1].

CNSL is a brownish viscous oil composed of phenolic compounds in proportions that vary according to the method of extraction. In general, the initial composition of natural CNSL (solvent-extracted) is a mixture of anacardic acid (70\%), cardanol (18\%), cardol (10\%) and 2-methylcardol (1\%) [8]. Our group isolated the CNSL compounds, obtaining seventeen molecules that had similar groups to sunscreen's active ingredients, the ultraviolet (UV) absorbers.

Additionally, CNSL is considered a versatile raw material for a series of chemical transformations due to the phenolic and lipid constituents' dualistic nature, including the aromatic and acyclic character, associated to the existence of many functional groups in the aromatic ring and presence of multiple unsaturations in the acyclic chain $[4,5]$. Concerning the chemical nature, ease of obtaining and control of chemical transformations in the structure of some of the CNSL phenolic constituents $[1,4,5]$, the present work was carried out aiming at a potential exploration of CNSL as raw material in the synthesis of new agents for protection against solar radiation. Fifteen CNSL-derived molecules were rationally planned as sunscreens (Patent number INPI No PI 0406040-7, WO 2006/042391A2). These derivatives present as main structural characteristics the photoabsorbent chromophoric patterns found in aromatic, cinnamic, sulphonic esters, as well as conjugated arylketones necessary for the photoprotection 
activity, along with the natural hydrophobic subunit comprised by the alkylic chain of the CNSL phenolic derivatives.

It is well known that solar ultraviolet radiation is the major etiological cause of skin cancer in humans [9]. Over a million cases are detected each year, whereas 132,000 new cases of cutaneous malignant melanomas occur worldwide each year [10]. Therefore, protection from UV light is a major strategy in the prevention of skin cancer, of which the most popular method is the use of sunscreen [11].

In this context, the aim of this study was to evaluate if the CNSL constituents and its derivatives molecules absorb in the ultraviolet, which is one of the characteristics of a substance to be classified as a sunscreen, to determine their Sun Protection Factor (SPF) using spectrophotometric methods, to study their physical-chemical properties and toxicity in silico, and perform in vitro assays.

\section{Experimental section}

\section{Chemicals and reagents}

Tetrahydrofuran, chloroform, ethanol and dimethyl sulfoxide were purchased from TEDIA (Brazil), Tween 80 and 4-NQO was from SIGMA-ALDRICH (Brazil). Sodium chloride, potassium dihydrogen phosphate, sodium phosphate dibasic dodecahydrate and glucose were from MERCK (Brazil). Yeast exctract, Bacto peptone and Bacto agar were from DIFCO (Brazil). Octyl p-methoxycinnamate was from PHARMA SPECIAL (Brazil).

Mixtures and isolated compounds from the natural and technical CNSL and their O-acetyl and O-methyl derivatives are shown in Figure 1. Rationally planned C15 and C8 CNSL-derivatives are depicted in Figures 2 and 3. Molecules were synthesized at Laboratório de Desenvolvimento de Estratégias Terapêuticas LADETER/UCB (MMA/CGEN authorization 167/2014 - Portaria $n^{\circ} 386$ de 22/10/2014).

\section{UV absorbance and in vitro SPF determination}

For determination of the specific absorbance $\left(\mathrm{A}_{\mathrm{lcm}}^{\mathrm{l} \%}\right)$ the samples were diluted at $1 \%(\mathrm{w} / \mathrm{v})$ in diferent solvents considering the solubility of each substance: ethanol (V1-31; V37), chloroform (V32-V35) and DMSO (V36). The absorption values in the ultraviolet range were determined using a Shimadzu UV-1601 spectrophotometer. The molar absorptivity $(\varepsilon)$ was calculated for each test solution at the wavelengths of maximum absorbance $(\lambda \max )[12]$.

In vitro SPF values were determined according to the method described by Mansur [13]. Absorbance values for each substance at 1 or $5 \%(\mathrm{w} / \mathrm{v})$, in the same solvents cited above, were determined in triplicate at a final concentration of $0.2 \mu \mathrm{L} / \mathrm{mL}$ and an emission spectrum of
290-320 nm with intervals of $5 \mathrm{~nm}$ using $1 \mathrm{~cm}$ quartz cuvettes in a Shimadzu UV-1601 spectrophotometer.

The SPF determination, equation (1) and the correlation between the erythemogenic effect $(\mathrm{EE})$ and the radiation intensity at each wavelength $(\mathrm{EE} \times \mathrm{I})$ were adjusted according to Sayre [14].

$$
\text { Spectrophotometric SPF }=\mathrm{CF} \sum_{290}^{320} \operatorname{EE}(\lambda) \mathrm{I}(\lambda) \text { abs }(\lambda)
$$

The correction factor $(\mathrm{CF})=10, \mathrm{EE}(\lambda)$ is the erythemogenic effect of radiation on wavelength $\lambda, I(\lambda)$ is the intensity of solar light with wavelength $\lambda$, and abs $(\lambda)$ is the spectrophotometric absorbance value of a solution of the preparation at wavelength $\lambda[14]$.

The in vitro SPF were also determined for mixture of V34 and V35 at 5\% and 10\% (w/v), and two comercial UV filters widely found in sunscreen formulations: octyl-p-methoxy-trans-cinnamate and octocrylene both at $10 \%(\mathrm{w} / \mathrm{v})$ in chloroform, this is the maximum concentration alowed by ANVISA for both substances in sunscreen formulations [15].

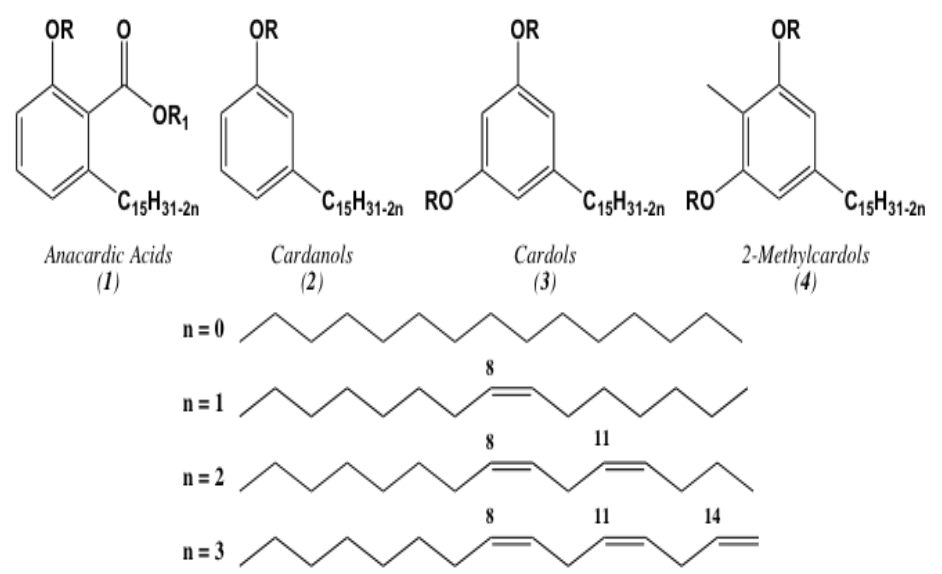

\begin{tabular}{cccccc}
\hline Number & $\begin{array}{c}\text { Compound } \\
\text { or Mixture }\end{array}$ & $\mathrm{N}$ & $\mathrm{R}$ & $\mathrm{R}_{1}$ & Code \\
\hline 1 & $1-4$ & $0-3$ & $\mathrm{H}$ & $\mathrm{H}$ & $\mathrm{V} 15$ \\
2 & $1-4$ & 0 & $\mathrm{H}$ & $\mathrm{H}$ & $\mathrm{V} 16$ \\
3 & $2-4$ & $0-3$ & $\mathrm{H}$ & $\mathrm{H}$ & $\mathrm{V} 17$ \\
4 & $2-4$ & 0 & $\mathrm{H}$ & $\mathrm{H}$ & $\mathrm{V} 18$ \\
5 & 1 & $0-3$ & $\mathrm{H}$ & $\mathrm{H}$ & $\mathrm{V} 9$ \\
6 & 1 & $0-3$ & $\mathrm{H}$ & $\mathrm{Me}$ & $\mathrm{V} 30$ \\
7 & 1 & $0-3$ & $\mathrm{Ac}$ & $\mathrm{H}$ & $\mathrm{V} 10$ \\
8 & 1 & $0-3$ & $\mathrm{Me}$ & $\mathrm{Me}$ & $\mathrm{V} 11$ \\
9 & 1 & 0 & $\mathrm{H}$ & $\mathrm{H}$ & $\mathrm{V} 12$ \\
10 & 1 & 0 & $\mathrm{Ac}$ & $\mathrm{H}$ & $\mathrm{V} 13$ \\
11 & 1 & 0 & $\mathrm{Me}$ & $\mathrm{Me}$ & $\mathrm{V} 14$ \\
12 & 2 & $0-3$ & $\mathrm{H}$ & -- & $\mathrm{V} 5$ \\
13 & 2 & $0-3$ & $\mathrm{Ac}$ & -- & $\mathrm{V} 6$ \\
14 & 2 & 0 & $\mathrm{H}$ & -- & $\mathrm{V} 7$ \\
15 & 2 & 0 & $\mathrm{Ac}$ & -- & $\mathrm{V} 8$ \\
16 & 2 & 0 & $\mathrm{Me}$ & -- & $\mathrm{V} 19$ \\
17 & 3 & $0-3$ & $\mathrm{H}$ & -- & $\mathrm{V} 1$ \\
18 & 3 & $0-3$ & $\mathrm{Ac}$ & -- & $\mathrm{V} 2$ \\
19 & 3 & 0 & $\mathrm{H}$ & -- & $\mathrm{V} 3$ \\
20 & 3 & 0 & $\mathrm{Ac}$ & -- & $\mathrm{V} 4$ \\
\hline
\end{tabular}

Figure 1. Constituents of CNSL (1-20) 
Number

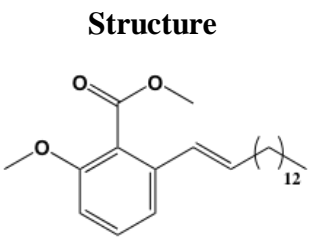

22

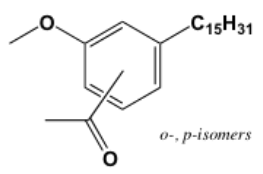

23

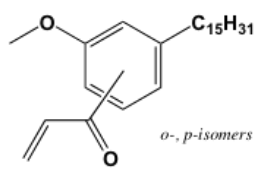

24

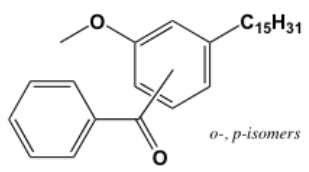

25<smiles>CCCCCCc1cccc(OC(=O)c2ccccc2)c1</smiles>

26<smiles>CCCCCCCCCCCCc1ccc(Cc2ccccc2)c(O)c1</smiles>

27<smiles>CCCCCCc1cccc(OC(=O)/C=C/c2ccccc2)c1</smiles>

28<smiles>CCCCCCCCc1cccc(OC(=O)/C=C/c2ccc(OC)cc2)c1</smiles>

Figure 2. Structures 21-28 of CNSL-derived molecules

\section{In silico studies}

The computational tool Osiris ${ }^{\circledR}$ Property Explorer (http://www.organic-chemistry.org/ prog/peo/, Actelion Pharmaceuticals, Ltd.) was used to calculate lipophilicity, expressed as octanol/water partition coefficient $(\log \mathrm{P})$; solubility in water, expressed as the 10-based logarithm of the solubility of a molecule measured in $\mathrm{mol} / \mathrm{L}(\operatorname{logS})$; molecular weight; druglikeness indices and drug scores; and toxicological properties such as mutagenic, tumorigenic, irritant and reproductive effects [16].

The substances studied were V32, V33, V34, V35, V36, V37, and compared with two commercial UV filters known for their toxic effects: 4-Methylbenzylidene camphor (4-MBC) and Benzophenone-3 (BP-3).

Number

29<smiles>COc1cccc2c1C(=O)OCCCCCCCC2</smiles>

Code

V26

30<smiles>COc1cccc(/C=C/CCCCCOC(=O)c2ccccc2OC)c1</smiles>

31<smiles>COc1cccc(CCOC(=O)/C=C/c2ccccc2)c1</smiles>

32<smiles>COc1ccc(/C=C/C(=O)OCCc2cccc(OC)c2)cc1</smiles>

V37

33<smiles>CCOC(=O)c1ccccc1CCOC(=O)c1ccccc1</smiles>

34<smiles>O=C(/C=C/c1ccccc1)OCCc1cccc(OC(=O)/C=C/c2ccccc2)c1</smiles>

35<smiles>COc1ccc(/C=C/C(=O)Oc2cccc(CCNC(=O)Oc3ccc(OC)cc3)c2)cc1</smiles>

Figure 3. Structures 29-35 of CNSL-derived molecules

\section{Mutagenicity assays}

The Ames method was used to assess mutagenicity [17]. Salmonella typhimurium auxotroph mutant strains TA 97 (hisD6610/ his01242 - $\Delta u v r \mathrm{~B}$ rfa pKM101 $\left(a m p^{R}\right)$ ), TA 98 (hisD3052 - $\Delta u v r \mathrm{~B}$ rfa pKM101 $\left(a m p^{\mathrm{R}}\right)$ ), TA100 (hisG46 - $\Delta u v r \mathrm{~B}$ rfa pKM101 $\left(a m p^{\mathrm{R}}\right)$ ), and the wild type strain TA102 (hisG428-wild type rfa pKM101 $\left(a m p^{R}\right)$ pAQ1 $\left.\left(t e t^{R}\right)\right)$ were grown in VogelBonner E Medium [17]. A 4-nitroquinoline 1-oxyde (4NQO) solution was used as a positive control for genotoxicity.

Samples were diluted in 5\% (V32-V37) or 10\% (V34 V35) tetrahydrofuran (THF). Aliquots of $10 \mu \mathrm{L}$ of each sample were applied directly onto the plates without ultraviolet irradiation to assess the mutagenic potential. 
Prior to application of the samples onto the plates, two other aliquots were put into glass flasks and irradiated with $20 \mathrm{~kJ} / \mathrm{m}^{2}\left(27 \mathrm{~J} / \mathrm{m}^{2} / \mathrm{s}\right.$ for 12'34") of UVA and 10 $\mathrm{kJ} / \mathrm{m}^{2}\left(7.8 \mathrm{~J} / \mathrm{m}^{2} / \mathrm{s}\right.$ for $\left.21^{\prime} 36^{\prime \prime}\right)$ of UVB radiation to evaluate the photomutagenic potential.

\section{Genotoxicity assays}

SOS Spot test and SOS chromotest, were carried out as previously described [18]. In both tests, E. coli PQ35 and PQ37 (uvrA rfa sfiA::lacZ) strains were used. Samples were diluted in 5\% THF (V32-V37) and divided into: non-irradiated and irradiated with UV radiation (two aliquots were removed, put into glass flasks, and irradiated with $20 \mathrm{~kJ} / \mathrm{m}^{2}\left(27 \mathrm{~J} / \mathrm{m}^{2} / \mathrm{s}\right.$ for $\left.12^{\prime} 34^{\prime \prime}\right)$ of UVA and $10 \mathrm{~kJ} / \mathrm{m}^{2}\left(7.8 \mathrm{~J} / \mathrm{m}^{2} / \mathrm{s}\right.$ for $\left.21^{\prime} 36 "\right)$ of UVB radiation. A 4NQO solution was used as a positive control of genotoxicity in both tests [18].

For the SOS chromotest, the induction of $\beta$-galactosidase expression and alkaline phosphatase were measured according to Quillardet \& Hofnung (1985) [18] and Miller (1972) [19]. The samples were applied directly on the plate containing the culture medium; before applying on the plates, two brackets of the samples were irradiated with UVA and UVB radiation, respectively, to evaluate the photogenotoxic potential of the substances.

The induction factor was calculated as previously described $[18,20]$. For the assays, samples V32, V34 and V36 were diluted to $1 ; 2.5 ; 4 ; 5 ; 10 \%(\mathrm{w} / \mathrm{v})$. The commercial sunscreen octyl p-methoxycinnamate was tested in the same dilutions.

Irradiation conditions: a lamp with emission in the 290$320 \mathrm{~nm}$ range and a peak at $312 \mathrm{~nm}$ was used (VL-215 LM, Vilber Lourmat, France). Fluence was measured using an appropriate sensor (Radiometer VLX-312, Vilber Lourmat-France).

\section{Phototoxicity assay using the yeast Saccharomyces cerevisiae}

A Saccharomyces cerevisiae wild type strain D273-10B was used and the assay was carried out as described previously [21]. Briefly, solutions of 8-methoxypsoralen and of octyl p-methoxycinnamate at $0.1 \%$ were employed as positive [22] and negative phototoxic activity controls, respectively. Ethanol was used as solvent. Aliquots of each studied substance (V1-V37 at $5 \% \mathrm{w} / \mathrm{v})$ were applied onto Whatman $\mathrm{n}^{\circ} 1$ sterile filter paper disks, which were fixed on the surface of the culture media plates.

A suspension of $S$. cerevisiae cells was prepared in sterilized water $(10 \mathrm{~mL})$. Aliquots of $0.2 \mathrm{~mL}$ were applied and spread in the culture plates using a glass loop. Two plates were prepared for each sample. After seeding and applying the samples, one plate was allowed to grow under two UVA lamps (320-390 nm). A control plate was grown in the dark.

For analysis of the results, the following aspects were observed:
- The presence of a clear zone around the test substance in the light and the absence in the dark indicate the sample phototoxicity;

- The absence of a clear zone around the test substance in the light and in the darkness indicates that the sample is not phototoxic [21].

\section{Results and Discussion}

\section{UV absorbance and in vitro SPF determination}

The ultraviolet absorption spectral properties $\left(\lambda_{\max }\right.$ and $\varepsilon$ values) of the tested substances in different solvents were obtained. The main characteristics of a UV absorption band are its wavelength of maximum absorbance $\left(\lambda_{\max }\right)$ and its molar absorptivity $(\varepsilon)$ [23]; both values are distinctive features for each substance [12].

The specific absorbance values are shown in Tables 1 and 2 . The higher specific absorbance values found were for V32 (1088) and V36 (1167) (table 2). The ideal for a UV filter is a specific absorbance value higher than 1000 , but many commercial UV filters show $\mathrm{A}_{\mathrm{lcm}}^{1 \%}$ lower than 1000 [24], such as 4-MBC (990) [25].

Table 1. UV spectral data of V1-V31 diluted in ethanol

\begin{tabular}{|c|c|c|c|}
\hline Substance & $\lambda_{\max }(\mathrm{nm})^{1}$ & $\mathrm{~A}_{\mathrm{lcm}}^{1 \%} 2$ & $\varepsilon^{3}$ \\
\hline V1 & 276 & 47 & 1495.5 \\
\hline V2 & 275 & 22 & 895.9 \\
\hline V3 & 275 & 47 & 1504.9 \\
\hline V4 & 274 & 29 & 1186.7 \\
\hline V5 & 275 & 46 & 1390.1 \\
\hline V6 & 270 & 15 & 516.3 \\
\hline V7 & 274 & 57 & 1733.9 \\
\hline V8 & 272 & 16 & 553.9 \\
\hline V9 & 302 & 64 & 2215.6 \\
\hline V10 & 301 & 31 & 1203.4 \\
\hline V11 & 280 & 51 & 1908.5 \\
\hline V12 & 305 & 88 & 3064.1 \\
\hline V13 & 304 & 57 & 2224.1 \\
\hline V14 & 280 & 62 & 2332.5 \\
\hline V15 & 299 & 77 & 2572.2 \\
\hline V16 & 302 & 70 & 2369.6 \\
\hline V17 & 275 & 53 & 1613.5 \\
\hline V19 & 275 & 50 & 1592.7 \\
\hline V20 & 282 & 708 & 29995.1 \\
\hline V21 & 285 & 29 & 1048.6 \\
\hline V23 & 266 & 316 & 12912.1 \\
\hline V24 & 221 & 499 & 18690.5 \\
\hline V26 & 280 & 77 & 2020.1 \\
\hline V27 & 292.5 & 101 & 2629.3 \\
\hline V29 & 275 & 398 & 16263.1 \\
\hline V30 & 245 & 98 & 3553.0 \\
\hline V31 & 229 & 586 & 25229.6 \\
\hline
\end{tabular}

${ }^{\mathrm{T}}$ Wavelength of maximum absorbance, ${ }^{2}$ Specific absorbance, ${ }^{3}$ Molar absorptivity.

The substances that showed the highest values of molar absorptivity were V20, V31 - V37 (Table 1 and 2). The molar absorptivity is directly proportional to the 
chemical's ability to absorb UV radiation, and it is affected by the nature of the solvent. Therefore, the higher the absorptivity, the more UV radiation the chemical absorbs [12].

Table 2. UV spectral data of V32-V37 diluted in different solvents

\begin{tabular}{lllll}
\hline Substance & $\boldsymbol{\lambda}_{\max }(\mathbf{n m})^{\mathbf{1}}$ & $\mathrm{A}_{\text {lcm }}^{1 \%}$ & $\boldsymbol{\varepsilon}^{\mathbf{3}}$ & Solvent \\
\hline V32 & 294 & 1088 & 52509.1 & Chloroform \\
\hline V33 & 280 & 528.1 & 20940.75 & Chloroform \\
\hline V34 & 284 & 500.4 & 21750.39 & Chloroform \\
\hline V35 & 315 & 635.5 & 29531.05 & Chloroform \\
\hline V36 & 331 & 1167 & 63329.6 & DMSO \\
\hline V37 & 309.6 & 418 & 16574.9 & Ethanol \\
\hline
\end{tabular}

${ }^{1}$ Wavelength of maximum absorbance, ${ }^{2}$ Specific absorbance,

${ }^{3}$ Molar absorptivity.

The molar absorptivity of V20, V29, V31, V33, V34, V35 and V37 were higher than BP-3 $(\lambda \max =287 \mathrm{~nm}, \varepsilon$ $=14460$, in etanol) [26]. While the $\varepsilon$ value of V32 and V36 molecules were at least 2 times higher than commertial many UV filters, such as octyl- $p$-methoxytrans-cinnamate $(\lambda \max =310 \mathrm{~nm}, \varepsilon=24000$, in ethanol $)$ [27], butyl methoxy dibenzoyl methane $(\lambda \max =359$ $\mathrm{nm} ; \varepsilon=32500$, in ethanol) [23], and 4-MBC ( $\lambda \max =$ $300 \mathrm{~nm}, \varepsilon=25183$, in metanol) [25].

Cui et al. (2012) [28] synthesized two novel Nheterocycle-containing benzotriazole compounds. The $\mathrm{UV}-\mathrm{Vis}$ spectra of one of the benzotriazole derivatives was measured in chloroform, and the molar absorptivity was 19500 at $339 \mathrm{~nm}(\lambda \max )$, a lower result than the values found for V31 - V37.

While the CNSL directly derived substances (V1-V20) and others synthesized from it (V20-V31) presented almost insignificant SPF values, substances V32, V33, V34, V35, V36 and V37 presented the best SPF values (table 3 ): $9.5 ; 1.5 ; 2.4 ; 4.2 ; 7.7$; and 5.2 , respectively; and the highest molar absorptivity values (table 2 ).

Table 3. Results of the sun protection factor (SPF) of substances V32 to V37 at 5\% (w/v), with the respective solvents.

\begin{tabular}{c|c|c}
\hline Substance & SPF $^{\mathbf{1}}$ & Solvent \\
\hline V32 & 9.5 & Chloroform \\
\hline V33 & 1.5 & Chloroform \\
\hline V34 & 2.9 & Chloroform \\
\hline V35 & 4.2 & Chloroform \\
\hline V36 & 7.7 & DMSO \\
\hline V37 & 5.2 & Ethanol
\end{tabular}

${ }^{1}$ Sun protection factor

Nowadays, organic UV absorbers used in sunscreens are aromatic compounds, each containing multiple conjugated $\pi$-electron systems [29]. Natural products with polyphenols and flavonoids have been studied as UV absorbers, due to their structural similarity to chemical filters, their lower cost, and some have multiple biological activities [30], such as antimicrobial and antioxidant [31].

Marto et al. (2016) [30] studied the green (GCO) and spent coffee oil (SCO), and found that GCO presented an
SPF value in ethanol of $5.03 \pm 0.23$ while SCO presented only $1.57 \pm 0.07$, but the authors did not specify the concentration used.

The ethanolic extract of Marcetia taxifolia was dissolved in ethanol, and extracts with different concentrations (25\% and $12.5 \%)$ had satisfactory sunscreen activity (SPF 15.52 and 8.35, respectively), the SPF values of the tested extracts were concentration-dependent. This activity was attributed to the flavonoids found in species of the Marcetia family [31]. We tested our compounds at 5\%, a lower concentration, and found higher SPF values, for V32 (SPF 9.2).

According to Wolf (2009) [32] each sunscreen active's concentration must be sufficient to contribute a minimum SPF of not less than 2 to the finished product. The V32-V37 molecules could be combined to get higher SPF values for the sunscreen product. For example, V34 and V35 do not have high SPF values, however a mixture V34 and V35 at 5\% and 10\% (w/v) in chloroform was tested by the Mansur method (table 4), resulting in an acceptable SPF value of $5.2(5 \%)$ and SPF 8,5 (10\%), which also indicates a compatibility between the tested molecules. While the mixture of these substances at $10 \%(\mathrm{w} / \mathrm{v})$ in resulted in SPF 8,5. The SPF value of a mixture containing octyl-p-methoxy-transcinnamate (OMC) and octocrylene both at $10 \%(\mathrm{w} / \mathrm{v})$ was also tested in chloroform and resulted in SPF 12.

Table 4. Results of SPF in vitro for mixtures of V34, V35 and commercial UV filters in chloroform.

\begin{tabular}{c|c|c}
\hline Mixture & Concentration (w/v) & $\mathbf{S P F}^{1}$ \\
\hline $\mathrm{V} 34+\mathrm{V} 35$ & $5 \%$ & 5.2 \\
\hline $\mathrm{V} 34+\mathrm{V} 35$ & $10 \%$ & 8,5 \\
\hline $\mathrm{OMC}^{2}+\mathrm{OC}^{3}$ & $10 \%$ & 12 \\
\hline $\begin{array}{l}{ }^{1} \text { Sun protection } \\
{ }^{3} \text { octocrylene }\end{array}$ & fator, ${ }^{2}$ octyl-p-methoxy-trans-cinnamate, \\
\end{tabular}

\section{In silico studies}

The results of cLogP for V32-V37 were between 6.3710.42 (table 5). For UV filters a cLogP > 5 are desirable because indicates that the substance will show low cutaneous permeability [24]. These values also show low oral bioavailability [33], suggesting a low toxicity if the substance is accidentally ingested. According to druglikeness and drug-scores results, V32-V37 do not qualify as new potential medicinal substances, also corroborating with the proposed topical and cosmetic use. The commercial filters BP-3 and 4-MBC showed cLogP $<5$ (table 5), indicating good oral absorption and cutaneous permeability. This indicates that the substances under study (V32-V37) could have lower toxicity than these commercial filters.

Experimental studies confirm substantial absorption and distribution of commercial filters. Organic UV filters, including BP-3 and 4-MBC, are easily absorbed by the skin and reach the systemic circulation, and accumulate in various tissues, such as adipose tissue, liver, brain and placenta. These filters seem to be associated with altered estrogen, androgen and progesterone activity, 
reproductive and developmental toxicity and impaired functioning of the thyroid, liver or kidneys [34].

None of the substances (V32-V37) showed mutagenic or tumorogenic risks (table 5). In silico approaches are widely used to study important parameters that may guide a medicinal chemist in the evaluation of chemical and physicochemical properties of a compound, and to avoid unnecessary expenses associated with biological assays of compounds with a high probability of presenting future toxicity risks, and thus save time and investments [35]. The ultraviolet filter BP-3, a substance approved by FDA and widely used showed toxicity risks (mutagenic, tumorogenic and reproductive) (table 5). There are studies that corroborate these results, which indicated estrogenic [36] and antiandrogenic activity of this compound [37].

Toxicity risk alerts are an indication that the drawn structure may be harmful concerning the risk category specified. Only V35 did not show fragments with potential irritant risk, and V37 showed a potential reproductive effect risk. However, risk alerts are by no means a fully reliable toxicity prediction, nor the absence of risk alerts should lead to the conclusion that a particular substance is completely free of any toxic effect [38]. The underlying principle of the program used, OSIRIS $®$, is to take advantage of existing information, to focus on non-animal tests and on non-test information as much as possible, to group information about similar substances and to integrate exposure considerations. Ideally, with regard to the $3 \mathrm{R}$ principle of Reduction, Refinement and Replacement of animal testing, nontesting (in silico) and experimental non-animal (in vitro) methods are preferred for this purpose [39].

In fact, in silico predictions do not replace or disqualify experimental tests, and both should work in partnership with each other. Experimental in vitro and in vivo tests are uniquely important for the evaluation of a new compound and should not be replaced by in silico studies [40].

\section{Mutagenicity}

The samples that presented the best SPF values, V32, V33, V34, V35, V36, V37 were selected for the mutagenic and genotoxic tests because these molecules are the most promising to be considered as new UV filters.

The photoreactivity of the UV filter Butyl methoxy dibenzoylmethane was investigated in different solvents, including tetrahydrofuran (THF) and it was stable after irradiation in a solar simulator at a complete dose of 60 $\mathrm{kJ} / \mathrm{m} 2$ (4 min interval at $250 \mathrm{~W} / \mathrm{m} 2$ ) [41]. Therefore, this solvent was used, besides it has no mutagenic or genotoxic potential risk [42], and was tested alone and did not show a mutagenic response.

Table 5. Toxicity risks and physicochemical properties of compounds V32-V37 in comparison with 4-Methylbenzylidene camphor and Benzophenone-3, predicted by OSIRIS Property Explorer.

\begin{tabular}{|c|c|c|c|c|c|c|c|c|c|}
\hline \multirow[t]{2}{*}{ Substance } & \multicolumn{4}{|c|}{ Toxicity risks } & \multicolumn{5}{|c|}{ Physicochemical properties } \\
\hline & Mutagenic & Tumorogenic & Irritant & $\begin{array}{c}\text { Reproductive } \\
\text { effect }\end{array}$ & $\mathrm{MW}^{1}$ & $\operatorname{clog} \mathrm{P}^{2}$ & Solubility & $\begin{array}{c}\text { Drug } \\
\text { Likeness }\end{array}$ & $\begin{array}{l}\text { Drug } \\
\text { Score }\end{array}$ \\
\hline V32 & $(-)$ & $(-)$ & $(+)$ & $(-)$ & 482 & 8.11 & -7.02 & -13.00 & 0.07 \\
\hline V33 & $(-)$ & $(-)$ & $(+)$ & $(-)$ & 366 & 6.41 & -5.2 & -12.98 & 0.12 \\
\hline V34 & $(-)$ & $(-)$ & $( \pm)$ & $(-)$ & 434 & 10.22 & -7.47 & -22.00 & 0.09 \\
\hline V35 & $(-)$ & $(-)$ & $(-)$ & $(-)$ & 464 & 10.12 & -7.49 & -20.20 & 0.11 \\
\hline V36 & $(-)$ & $(-)$ & $(+)$ & $(-)$ & 542 & 7.9 & -7.06 & -11.2 & 0.06 \\
\hline V37 & $(-)$ & $(-)$ & $(+)$ & $(+)$ & 396 & 6.37 & -5.22 & -11.39 & 0.07 \\
\hline $\mathrm{BP}-3^{3}$ & $(+)$ & $(+)$ & $(-)$ & $(+)$ & 228 & 2.85 & -3.44 & 0.08 & 0.14 \\
\hline $4-\mathrm{MBC}^{4}$ & $( \pm)$ & $(-)$ & $(-)$ & $(-)$ & 254 & 4.29 & -4.19 & -6.64 & 0.28 \\
\hline
\end{tabular}

${ }^{\mathrm{I}}$ Molecular weight (g/mol), ${ }^{2}$ Lipophilicity, ${ }^{3}$ Benzophenone-3, ${ }^{4}$ 4-Methylbenzylidene camphor.

The samples tested through the Ames method, at 5\% (V32, V33, V34, V35, V36, V37), and 10\% (V34, V35) in THF, did not demonstrate mutagenic or photomutagenic activity $(n=3)$. The non-irradiated samples did not demonstrate mutagenicity when compared to the positive control for this test, 4NQO. When the samples were irradiated with UVA and UVB radiation, they did not show a photomutagenic response either $(n=3)$. These results corroborate the predicted from the in silico results.

Carvalho et al (2011) [43] investigated the mutagenic, acute and subacute toxicity of anacardic acids isolated from CNSL, performing in vivo assays via $\mathrm{BALB} / \mathrm{c}$ mice, and they did not produce any mutagenic effects, or biochemical and hematological alterations using doses under $300 \mathrm{mg} / \mathrm{kg}$.

\section{Genotoxicity}

The non-irradiated and samples that were irradiated with UVA and UVB radiation, V33, V35, and V37 (at 5\% in THF) did not present blue halos for PQ35 and PQ37, indicating they were non-genotoxic in the tested concentration $(n=3)$. The THF solvent was tested alone and did not demonstrate genotoxic activity.

Samples V32, V34 and V36 (at 5\% in THF) presented a light blue halo just for strain PQ37, when irradiated with UVA and UVB radiation, they demonstrated a light genotoxicity and cytotoxicity for both strains $(n=3)$. Therefore, the SOS Chromotest was used for quantification of this supposed genotoxicity (table 6). 
Table 6. Genotoxic activity of the V32, V34, V36, octyl pmethoxycinnamate substances in culture of E. coli (PQ37) (n=3).

\begin{tabular}{|c|c|c|c|c|}
\hline Substance & $\begin{array}{c}\text { Concentration } \\
(\mathrm{g} \%)\end{array}$ & $\begin{array}{l}\text { Unit } \\
\mathbf{A F}^{1}\end{array}$ & $\begin{array}{l}\text { Units } \\
\beta \text {-gal }\end{array}$ & IF $^{3}$ \\
\hline \multirow{6}{*}{ V32 } & 0 & 0.067 & 0.551 & 0.424 \\
\hline & 1 & 0.121 & 0.376 & 0.375 \\
\hline & 2.5 & 0.151 & 0.612 & 0.492 \\
\hline & 4 & 0.076 & 0.464 & 0.739 \\
\hline & 5 & 0.092 & 0.372 & 0.489 \\
\hline & 10 & 0.096 & 0.235 & 0.296 \\
\hline \multirow{6}{*}{ V34 } & 0 & 0.067 & 0.551 & 0.424 \\
\hline & 1 & 0.124 & 0.784 & 0.765 \\
\hline & 2.5 & 0.077 & 0.725 & 1.136 \\
\hline & 4 & 0.229 & 0.772 & 0.407 \\
\hline & 5 & 0.201 & 0.797 & 0.479 \\
\hline & 10 & 0.155 & 0.861 & 0.674 \\
\hline \multirow{4}{*}{ V36 } & 0 & 0.075 & 1.599 & 1.097 \\
\hline & 1 & 0.079 & 0.972 & 0.577 \\
\hline & 2.5 & 0.053 & 0.773 & 0.677 \\
\hline & 5 & 0.059 & 0.154 & 0.123 \\
\hline \multirow{6}{*}{$\mathrm{OMC}^{4}$} & 0 & 0.067 & 0.551 & 0.424 \\
\hline & 1 & 0.078 & 0.753 & 1.16 \\
\hline & 2.5 & 0.241 & 0.647 & 0.32 \\
\hline & 4 & 0.0493 & 0.488 & 1.19 \\
\hline & 5 & 0.086 & 0.614 & 0.85 \\
\hline & 10 & 0.080 & 0.639 & 0.966 \\
\hline
\end{tabular}

${ }^{1}$ Alkaline phosphatase, ${ }^{2} \beta$-gal - $\beta$-galactosidase, ${ }^{3}$ Induction factor, ${ }^{4}$ Octyl p-methoxycinnamate

A compound is classified as "non-genotoxic" if the induction factor remains <1.5; as "marginal" if the induction factor is between 1.5 and 2.0; and as "genotoxic" if the induction factor exceeds 2.0 [44].

Substances V32, V34 and V36, at concentrations varying from $1 \%$ to $10 \%$, presented induction factors lower than 1.5 (table 6), being considered non-genotoxic. Additionally, their induction factors were lower compared to octyl p-methoxycinnamate, a very used and non-genotoxic sunscreen, approved for use by FDA and by Brazil's regulatory organ (ANVISA).

Phenolic lipids, like anacardic acid, cardanol and cardol present in the CNSL can be incorporate by erythrocytes and liposomal membranes, exerting antigenotoxic activity [1]. The novel molecules under study derived from these phenolic lipids also showed no genotoxic effect.

\section{Phototoxicity in vitro}

None of the 35 tested substances at $5 \%(\mathrm{w} / \mathrm{v})$ led to the appearance of growth inhibition halos in both plates (irradiated and in the absence of light) demonstrating no phototoxic result (figure 4).

The positive control for phototoxicity, 8methoxypsoralen resulted in the appearance of growth inhibition halo in the irradiated plates (figure 5); and octyl $p$-methoxycinnamate did not promote the appearance of growth inhibition halo.

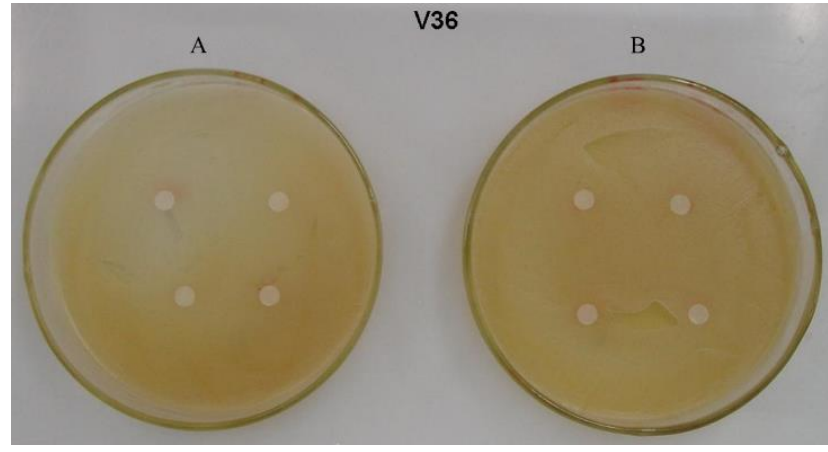

Figure 4. Negative result of phototoxicity V36: absence of growth inhibition halos in the plate irradiated with UV light (A) and in the absence of light plate (B).

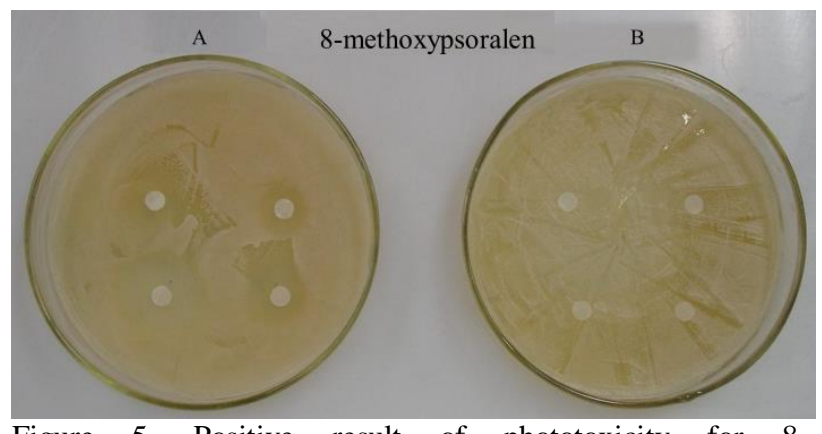

Figure 5. Positive result of phototoxicity for 8methoxypsoralen: presence of growth inhibition halo in the plate irradiated with UV light (A).

It is particularly important to test the phototoxic potential of pharmaceuticals and cosmetic products because the photoexcited forms of certain chemical compounds are known to produce phototoxic insult to cellular biomolecules [45].

\section{Conclusions}

Six of the 37 molecules studied showed potential to be used as new UV filters, showed appropriate SPF values, and demonstred to be non-phototoxic, non-genotoxic and non-mutagenic and the in silico results also indicated low cutaneous permeability and low oral bioavaibility. Moreover, these substances may have a lower cost because they are derived from the cashewnut that has an abundant industrial production in Brazil.

The use of this structural pattern for sunscreens has not been previously reported, and, therefore, the compounds tested in this study and their synthetic methodology represent a novelty among the organic photoprotective agents. Additionally, these compounds conjugate, in a single structure, different photoabsorbent chromophores, providing relevant synthesis cost reduction in relation to the isolated molecules found in the literature and in the market.

\section{Acknowledgments}

Recognition is due to $\mathrm{CNPq}$ (process number 310509/2011-4) for the fellowship to L.A.S. Romeiro. 
The authors also gratefully acknowledge the help from the colleagues from UFRJ - Rio de Janeiro/Brazil: Zaida Freitas, Célia Santos da Silva, Elisabete P. Santos, Luiz Mauricio T.R. Lima and Ana Luisa P. Miranda.

\section{Conflict of interest}

The authors declare that there is no conflict of interests regarding the publication of this article.

\section{References}

1. Andrade TJAS, Araújo BQ, Citó AMGL, Silva J, Saffi J, Richter MF, Ferraz ABF. Antioxidant properties and chemical composition of technical Cashew Nut Shell Liquid (CNSL). Food Chem. 2011; 126:1044-1048. http://dx.doi.org/10.1016/j.foodchem.2010.11.122

2. Konan NA, Bacchi EM, Lincopan N, Varela SD, Varanda EA. Acute, subacute toxicity and genotoxic effect of a hydroethanolic extract of the cashew (Anacardium occidentale L.) J. of Ethnopharmacol. 2007; $110: 30-38$ http://dx.doi.org/10.1016/j.jep.2006.08.033.

3. Monteiro FM, Medeiros E Silva GM, Silva JBR, Porto CS, Carvalho Jr. LB, Fijlho JLL, et al. Immobilization of trypsin on polysaccharide film from Anacardium occidentale L. and its application as cutaneous dressing. Process Biochem. 2007; 42:884-888. http://dx.doi.org/10.1016/j.procbio.2007.01.006.

4. Yuliana M, Tran-Thi NY, Ju YH. Effect of extraction methods on characteristic and composition of Indonesian cashew nut shell liquid. Ind. Crop. and Prod. 2012; 35:230-236. http://dx.doi.org/10.1016/j.indcrop.2011.07.007.

5. Maia FJN, Ribeiro VGP, Lomonaco D, Luna FMT, Mazzetto SE. Synthesis of a new thiophosphorylated compound derived from cashew nut shell liquid and study of its antioxidant activity. Ind. Crop. and Prod. 2012; $36: 271-275$. http://dx.doi.org/10.1016/j.indcrop.2011.10.019.

6. Kasemsiri P, Hiziroglu S, Rimdusit S. Effect of cashew nut shell liquid on gelation, cure kinetics, and thermomechanical properties of benzoxazine resin. Thermochim. Acta 2011; 520:84-92. http://dx.doi.org/10.1016/j.tca.2011.03.020.

7.Papadopoulou E, Chrissafis K. Thermal study of phenol-formaldehyde resin modified with cashew nut shell liquid. Thermochim. Acta 2011; 512:105-109. http://dx.doi.org/10.1016/j.tca.2010.09.008.

8. Maia FJN, Ribeiro FWP, Gomesrangel JH, Lomonaco D, Luna FMT, Lima-Neto P, et al. Evaluation of antioxidant action by electrochemical and acceleratedoxidation experiments of phenolic compounds derived from cashewnut shell liquid. Ind. Crop. and Prod. 2015; 67:281-286. http://dx.doi.org/10.1016/j.indcrop.2015.01.034.

9. Kozma B, Eide MJ. Photocarcinogenesis: An Epidemiologic Perspective on Ultraviolet Light and
Skin Cancer. Dermatol. Clin. 2014; 32:301-313. http://dx.doi.org/10.1016/j.det.2014.03.004.

10. Simões MCF, Sousa JJS, Pais AACC. Skin cancer and new treatment perspectives: A review. Cancer Lett. 2015; 357:8-42. http://dx.doi.org/10.1016/j.canlet.2014.11.001

11. Mancebo SE, Hu JY, Wang SQ. Sunscreens A Review of Health Benefits, Regulations, and Controversies. Dermatol. Clin. 2014; 32:427-438. http://dx.doi.org/10.1016/j.det.2014.03.011.

12. Shaath NA. The chemistry of sunscreens. In: Lowe NJ, Shaath NA. Sunscreens: development, evaluation and regulatory aspects. New York: Marcel Dekker; 1997, v.15, p.263-283.

13. Mansur JS, Breder MNR, Mansur MCA, Azulay RD. Determinação do fator de proteção solar por espectrofotometria. An. Bras. Dermatol. 1986; 61:121-124.

14. Sayre RM, Agin PP, Scans Vee GJ, Marlowe E. A comparison of in vivo and in vitro testing of sunscreening formulas. Photochem. Photobiol. 1979; 29:559-66. http://dx.doi.org/10.1111/j.17511097.1979.tb07090.

15. Agência Nacional de Vigilância Sanitária (Anvisa). Resolução RDC n 69 de 23 de março de 2016. Dispõe sobre Regulamento técnico mercosul sobre lista de filtros ultravioletas permitidos para produtos de higiene pessoal, cosméticos e perfumes. Brasília, Brazil: Diário Oficial da União; 2016. https://www.in.gov.br/materia/-

/asset_publisher/Kujrw0TZC2Mb/content/id/225503 00/do1-2016-03-24-resolucao-rdc-n-69-de-23-demarco-de-2016-22550243

16. Brito MA. Pharmacokinetic study with computational tools in the medical chemistry. Braz. J. of Pharm. Sci. 2011; 47:797-805. http://dx.doi.org/10.1590/S198482502011000400017

17. Maron DM, Ames B. Revised methods for the Salmonella mutagenicity test. Mutat. Res. 1983; 113:173-215. PMID:6341825

18. Quillardet P, Hofnung P. The SOS Chromotest, a colorimetric bacterial assay for genotoxins: procedures. Mutat. Res. 1985; 147:65-78. http://dx.doi.org/10.1016/0165-1161(85)90020-2.

19. Miller JH. Experiments in molecular genetics. New York: Cold Spring Harbor Laboratory; 1972, p.352355.

20. Asad LM, Asad NR, Silva AB, Almeida CE, Leitão AC. Role of SOS and OxyR systems in the repair of Escherichia coli submitted to hydrogen peroxide under low iron conditions. Biochim. 1997; 79:359$364 . \quad$ http://dx.doi.org/10.1016/S03009084(97)80030-2.

21. Freitas ZMF, Machado PA, Dellamora-Ortiz GM, Santos EP, Gonçalves JCS. Evaluation of phototoxicity of different sunscreens: 1,2,3propanetriol 1,3-dipalmitoyl-2-p-methoxycinnamoyl and 1,2,3-propanetriol 1,3-dioctanoyl-2- $p$ - 
methoxycinnamoyl. S.T.P. Pharma Sci. 2000; 10:239-242.

22. Spielmann H, Balls M, Dupuis J, Pape WJ, Pechovitch G, De Silva O, et al. The International EU/COLIPA In Vitro Phototoxicity Validation Study: Results of Phase II (Blind Trial). Part 1: The 3T3 NRU Phototoxicity Test. Toxicol. in vitro 1998; 12:305-327. 2333(98)00006-X

23. Agrapidis-Paloympis LE, Nash RA, Shaath NA. The effect of solvents on the ultraviolet absorbance of sunscreens. J. Soc. Cosmet. Chem. 1987; 38:209221.

http://journal.scconline.org/pdf/cc1987/cc038n04/p0 0209-p00221.pdf

24. Nascimento LF, Santos EP, Aguiar AP. Fotoprotetores Orgânicos: Pesquisa, Inovação e a Importância da Síntese Orgânica. Rev. Virtual Quim. 2014; 6(2):190-223. DOI: 10.5935/19846835.20140015

25. HENRIQUES BG. Desenvolvimento e avaliação de preparações Lipossomais contendo filtros solares sólidos UVA e UVB [dissertation]. Rio de Janeiro (RJ): Universidade Federal do Rio de Janeiro; 2008. http://objdig.ufrj.br/59/teses/696343.pdf

26. SANTOS VM. Preparação de filtros solares em nanosistema visando à maior ação fotoprotetora [dissertation]. Rio de Janeiro (RJ): Universidade Federal do Rio de Janeiro; 2007. http://objdig.ufrj.br/59/teses/683057.pdf

27. Pattanaargson S, Munhapol T, Hirunsupachot $P$, Luangthongaram P. Photoisomerization of octyl methoxycinnamate. J. of Photochem. and Photobiol. A: Chem. 2004; 161:269-274. doi:10.1016/S10106030(03)00282-X

28. Cui ZH, Wang XD, Guo JC, Chen WG. Synthesis, spectroscopic properties and applications of novel Nheterocycle-containing benzotriazoles as UV absorbers. Chin. Chem. Lett. 2012; 23:1019-1022. http://dx.doi.org/10.1016/j.cclet.2012.06.024

29. Jansen R, Osterwalder U, Wang SQ, Burnett M, Lim HW. Photoprotection. Part II. Sunscreen: Development, efficacy, and controversies. J. of the Am. Acad. of Dermatol. 2013; 69:867.e1-14. http://dx.doi.org/10.1016/j.jaad.2013.08.022

30. Marto J, Gouveia LF, Chiari BG, Paiva A, Isaac V, Pinto $\mathrm{P}$, et al. The green generation of sunscreens: Using coffee industrialsub-products. Ind. Crop. and Prod. 2016; 80:93-100. http://dx.doi.org/10.1016/j.indcrop.2015.11.033

31. Costa SCC, Detoni CB, Branco CRC, Botura MB, Branco A. In vitro photoprotective effects of Marcetia taxifolia ethanolic extract and its potential for sunscreen formulations. Rev. bras. de Farmacogn. 2015; 25:413-418. http://dx.doi.org/10.1016/j.bjp.2015.07.013

32. Wolf P, Young A. Photoprotection. In: Dermatological phototherapy and photodiagnostic methods. Berlin: Springer; 2009, p. 333-363. ISBN: 978-3-540-36692-8
33. Lipinski CA. Lead and Drug-Like Compounds: The Rule-of-Five Revolution. Drug Discov. Today Technol. 2004; 1:337-341. http://dx.doi.org/10.1016/j.ddtec.2004.11.007.

34. Ruszkiewicz JA, Pinkas A, Ferrer B, Peres TV, Tsatsakis A, Aschner M. Neurotoxic effect of active ingredients in sunscreen products, a contemporary review. Toxicol. Rep 2017; 4:245-259 DOI: 10.1016/j.toxrep.2017.05.006

35. Kadan RU, Roy N. Recent trends in drug likeness prediction: a comprehensive review of in silico methods. Indian J. Pharm. Sci. 2007; 69:609-615. http://dx.doi.org/10.4103/0250-474X.38464.

36. Morohoshi K, Yamamoto H, Kamata R, Shiraishi F, Koda T, Morita M. Estrogenic activity of 37 components of commercial sunscreen lotions evaluated by in vitro assays. Toxicol. in Vitr. 2005; 19:457-469. http://dx.doi.org/10.1016/j.tiv.2005.01.004

37. Suzuki T, Kitamura S, Khota R, Sugihara K, Fujimoto N, Ohta S. Estrogenic and antiandrogenic activities of 17 benzophenone derivatives used as UV stabilizers and sunscreens. Toxicol. and Appl. Pharmacol. 2005; 203:9-17. http://dx.doi.org/10.1016/j.taap.2004.07.005

38. Nalini CN, Raga Deepthi S, Ramalakshmi N, Uma G. Toxicity risk assessment of isatins. Rasayan J. of Chem. 2011; 4: 829-833. ISSN: 0974-1496

39. Vermeire T, Aldenberg $T$, Buist $H$, Escher $S$, Mangelsdorf I, Pauné E, et al. Osiris, a quest for proof of principle for integrated testing strategies of chemicals for four human health endpoints. Regul. Toxicol. Pharmacol. 2013; 67:136-145. http://dx.doi.org/10.1016/j.yrtph.2013.01.007

40. Agência Nacional de Vigilância Sanitária (Anvisa). Guia para avaliação de segurança de produtos cosméticos. $\quad 2^{\mathrm{a}}$. Ed. Brasília, 2012. http://portal.anvisa.gov.br/wps/wcm/connect/92f15c0 04e219a73a96dbbc09d49251b/Guia_cosmeticos_gra fica_final.pdf?MOD=AJPERES

41. Kockler J, Oelgemöller M, Robertson S, Glass BD. Photostability of sunscreens. J. of Photochem. and Photobiol. C: Photochem. Rev. 2012; 13:91-110. doi: 10.1016/j.jphotochemrev.2011.12.001

42. Lv Z, Yao Y, Lv Z, Min H. Effect of tetrahydrofuran on enzyme activities in activated sludge. Ecotoxicol. and environ. Saf. 2008; 70:259-265. doi:10.1016/j.ecoenv.2007.06.001

43. Carvalho ALN, Annoni R, Silva PRP, Borelli P, Fock RA, Trevisan MTS, et al. Acute, subacute toxicity and mutagenic effects of anacardic acids from cashew (Anacardium occidentale Linn.) in mice. J. of ethnopharmacol. 2011; 135(3):730-736. doi:10.1016/j.jep.2011.04.002

44. Kevekordes S, Mersch-Sundermann V, Burghaus CM, Spielberger J, Schmeiser HH, Arlt VM, et al. SOS induction of selected naturally occurring substances in Escherichia coli (SOS chromotest). Mutat. Res. 1999; 445:81-91. http://dx.doi.org/10.1016/S1383-5718(99)00141-2 
45. Verma K, Agrawal N, Misra RB, Farooq M, Hans RK. Phototoxicity assessment of drugs and cosmetic products using E. coli. Toxicol. in vitro 2008; 22:249-253. doi:10.1016/j.tiv.2007.08.009 